\title{
FORUM
}

Submitted 14.03.2013. Approved 21.07.2013

Evaluated in a double blind review process. Scientific Editors: Edgard Barki, Delane Botelho e Juracy Parente

DOI: http://dx.doi.org/10.1590/S0034-75902013005000005

\section{IS CATEGORY MANAGEMENT IN SMALL SUPERMARKETS WORTH THE EFFORT?}

\author{
Gerenciamento por categorias em pequenos supermercados compensa o esforço? \\ ¿Gestión de categorías en minimercados vale la pena el esfuerzo?
}

\begin{abstract}
Category management (CM) is an important tool to strengthen the relationship between manufacturers and retailers. This process has been associated with large corporate retailers; however, some recent researches show that $C M$ is open to companies of any type or size. This possibility is important in emerging markets, where neighborhood supermarkets are still representative and are often considered an alternative for manufacturers to achieve higher margins compared to big chains. In this context, the aim of this research was to analyze the results of a CM initiative in small neighborhood supermarkets from a manufacturer perspective. Data for the study comes from a food manufacturer in Brazil that implemented a CM process with 180 small retailers. A quantitative analysis was conducted in order to analyze the effect of the program on the food manufacturer's sales and market share. Our analysis suggests an overall positive effect of the program on both, sales and market share.
\end{abstract}

KEYWORDS / Category Management, Marketing, Distribution Channels, Food Retailing, Emerging Markets.

\section{RESUMO}

A Gestão de categorias (GC) é uma ferramenta importante para se fortalecer o relacionamento entre fabricantes e varejistas. Esse processo tem sido associado a grandes varejistas corporativos; contudo, algumas pesquisas recentes mostram que o GC está aberto a empresas de qualquer tipo ou tamanho. Esta possibilidade é importante para mercados emergentes, onde os mercados de bairro ainda são representativos, sendo frequentemente considerados como uma alternativa, para que os fabricantes atinjam margens mais altas do que aquelas alcançadas pelas redes de supermercados maiores. Nesse contexto, o objetivo desta pesquisa foi o de analisar os resultados da iniciativa do de GC, em minimercados de bairro, de uma perspectiva manufatureira. Os dados usados para a elaboração do estudo vêm de uma fabricante de alimentos no Brasil, que implantou um processo de GC junto a 180 pequenos varejistas. Foi utilizada uma análise quantitativa, com o fim de se analisar o efeito do programa nas vendas e na participação de mercado, por parte da fabricante de alimentos. Nossa análise sugere um efeito final positivo do programa, tanto em termos de vendas quanto sobre a participação de mercado.

PALAVRAS-CHAVE | Gestão de categorias, mercado, canais de distribuição, varejo de alimentos, mercados emergentes.

leandro.guissoni@fgv.br

Professor at Escola de Administração de Empresas de São Paulo, Fundação Getulio Vargas - São Paulo - SP, Brazil

\section{MATHEUS ALBERTO CONSOLI}

consoli@markestrat.org Project Coordinator at Center of Research and Projects in Marketing and Strategy, Markestrat - Ribeiro Preto - SP, Brazil

\section{JONNY MATEUS RODRIGUES}

jonnymateus@usp.br

Master's in Business Administration at Faculdade de Economia

Administração e Contabilidade de Ribeirão Preto, Universidade de São Paulo - Ribeirão Preto - SP, Brazil

\section{RESUMEN}

La Gestión de categorías (GC) es una herramienta importante para fortalecer la relación entre fabricantes y minoristas. Este proceso ha sido asociado a grandes minoristas corporativos; a pesar de eso, algunos datos recientes muestran que el GC está abierto a empresas de cualquier tipo o tamaño. Esta posibilidad es importante para mercados emergentes, donde los mercados de barrio todavía son representativos, siendo frecuentemente considerados como una alternativa, para que los fabricantes alcancen márgenes más altos que en aquellas alcanzadas en las redes de supermercados mayores. En ese contexto, el objetivo de esta investigación fue la de analizar los resultados de la iniciativa del GC, en minimercados de barrio, desde una perspectiva manufacturera. Los datos usados para la elaboración del estudio vienen de un fabricante de alimentos en Brasil, que implantó un proceso de GC junto a 180 pequeños comerciantes. Se utilizó un análisis cuantitativo, con el fin de analizar el efecto del programa en las ventas y en la participación de mercado, por parte del fabricante de alimentos. En nuestro análisis se sugiere un efecto final positivo del programa, tanto en términos de ventas cuanto sobre la participación de mercado.

PALABRAS-CLAVE / Gestión de categorías, mercado, canales de distribución, minoristas de alimentos, mercados emergentes. 


\section{PROBLEM STATEMENT AND OBJECTIVES}

According to Gooner, Morgan and Perreault Jr. (2011, p.18) "there is little conceptual development or empirical evidence concerning Category Management best practices". In the context of category management, our research contributes to bridge this gap in the literature by showing the worth of a category management (CM) process according to an additional perspective in this area; that is, from a manufacturer perspective applied to a neighborhood store environment in one emerging market.

The Category Management Report (1995) defines CM practices as the distributor/supplier process of managing categories as strategic business units, improving business results by focusing on delivering consumer value. Even though CM has become popular, especially associated with large companies in developed markets, Arkader and Ferreira (2004) conclude that its practices can be suited to companies of any type and size. This finding is important when observing the movement of global firms since they are also interested in developing business in new markets, such as emerging markets; specifically, they want to discover effective strategies and marketing practices in emerging markets (SHETH, 2011).

In terms of retailing, as neighborhood supermarkets are more prevalent in emerging markets than developed markets (CHATTERJEE and others, 2011), the challenge faced by consumer packaged goods (CPG) companies will be to identify strategies that are appropriate for this channel. Under this context, CM might be an alternative to be investigated for this channel. In this sense, we question whether a CM initiative in an emerging market is worth the effort from a large supplier perspective, once this company has employed some of the CM tools in order to increase sales by establishing a better relationship with family-owned neighborhood supermarkets in Brazil.

This investigation is important for three main reasons. First, researches on CM often analyze results only from the perspective of large corporate retailers, but neglect the manufacturer's role in this process (ARKADER and FERREIRA, 2004, p. 44) or its implementation in another channel type.

The second reason is because independent stores will tend to play an important role over coming years in emerging markets (CHATTERJEE and others, 2011; KERTESZ and others, 2011; DÍAZ, LACAYO, SALCEDO, 2007). However, it is important to note that independent retailers that own small supermarkets in emerging markets, such as Brazil, are under increasing pressure. Ailawadi, Borin and Farris (1995) found that some large retailers are gaining power over other retailers. As global retailers are also growing their business in emerging markets, independent supermarkets are struggling. This can be seen as an oppor- tunity for CPGs to provide them with some support, such as CM practices, under this competitive environment.

Finally, CPGs can achieve higher margins selling to independent stores in these markets (DÍAZ, LACAYO, SALCEDO, 2007), and also due to the fact that small retailers have a considerable share of retail sales in emerging markets. This knowledge has led to growing competition for sales in this channel; thus, CPG companies should develop and analyze the results of specific activities focused on family-owned independent supermarket channels.

In this way, marketing literature should not overlook the effects of a CM implementation under a different environment, such as with small neighborhood stores in an emerging market. For practitioners, this assessment can contribute to make better decisions regarding strategies designed for smaller supermarkets.

In an attempt to propose contributions on this subject, bringing category management concepts to be analyzed under a small retailer environment, and due to its relevance in a high competitive environment in Brazil, the research problem we address in this paper is defined as follows: what are the effects of a category management program with small neighborhood supermarkets on the manufacturer's sales and market share? Is it worth the effort?

In this research, a discussion is proposed in order to bring category management to the attention of researchers and practitioners, considering the analysis of sales and market share outcomes from a field experiment after the implementation of a CM program by a global food manufacturer along with 180 small supermarkets in Brazil.

In the article, the next section outlines the conceptual background based on relevant literature related to the proposal of this paper, followed by a review of the aspects regarding channel environment in emerging markets, methods, procedures, results and conclusions.

\section{CONCEPTUAL BACKGROUND AND HYPOTHESES}

The literature review for this paper is based on the following topics: category management, shopper marketing and sales force execution.

\section{Category management}

Companies are trying to adapt their demand chain management in order to protect their sales and market share; thus, adapting marketing and supply chain competencies can be a source of 
competitive advantage for suppliers and retailers to succeed in a highly competitive market by establishing positive channel relationships (JUTTNER, CHRISTOPHER, BAKER, 2007).

Aspects of channel relationships have received considerable amount of attention from researchers (ETGAR, 1978; FRAZIER and SUMMERS, 1984; ANDERSON and NARUS, 1990; AlLAWAD, BORIN, FARRIS, 1995; GANESAN and others, 2009; RUNYAN, STERNQUIST, CHUNG, 2010). Specifically, there are a lot of types of actions that have a negative repercussion and can threaten the supplier-retailer relationship (HIBBARD, KUMAR, STERN, 2001). In order to avoid this type of situation and a negative repercussion in the supplier-retailer relationship (e.g., activation of point of sales materials and retail alignment), category management can contribute by aligning the interests of both parties in order to stimulate sales and a better point-of-sale shopping experience for consumers (DUSSART, 1998; GOONER, MORGAN, PERREAULT JR, 2011).

According to Gooner, Morgan and Perreault Jr. (2011, p. 18) “in increasingly competitive markets, managers and scholars must rethink traditional approaches to creating and capturing value, including how inter-organizational relationships are handled". For CPGs, category management is often considered a breakthrough in trade practices (DUSSART, 1998) and offers conditions to strengthen the relationship between a food supplier and its marketing channels, bringing positive elements to supplier-retailer interaction (LINDBLOM and OLKKONEN, 2008).

Dussart (1998) analyzes that a shift from brand management to a category management approach is of importance because consumer decisions for one specific brand (e.g., coca-cola) can have an influence in the role category offered by one store (e.g, beverages). As a category management process offers conditions to manage product categories as business units, the interests from food manufacturers, retailers and shoppers can be combined and integrated in order to deliver value for both of them.

Moreover, CM tactics also deal with assortment, space allocation, and in-store promotional activity (LINDBLOM and OLKKONEN, 2008). As these elements have a large influence on sales and market share, a CPG should implement this process to improve its competitiveness. Moreover, this practice has been largely associated with the relationship between suppliers and large retailers, improving in-store marketing.

Arkader and Ferreira (2004) have investigated the importance of a category management initiative in Brazil, from the retailer perspective. The authors conclude that this practice is of importance in the context of some changes that took place in the $90 \mathrm{~s}$, and "there is an indication from this study that the cat- egory management process is open to companies of any type or size" (ARKADER and FERREIRA, 2004, p. 50).

Considering the findings of Arkader and Ferreira (2004), this research is important because contrary to traditional research on category management, our data comes from a CM process implemented by a food CPG company with small supermarkets that do not belong to big chains, which are still important in this kind of market; that is, we propose to analyze the CM process from a different application, because its practices can be suited to companies of any type or size.

On the other hand, in spite of its importance, there is still a lack of research on category management (DHAR, HOCH, KUMAR, 2001; GRUEN and SHAH, 2000; GOONER, MORGAN, PERREAULT JR, 2011). As a consequence, "managers have no comprehensive evidence-based guidance regarding whether more intensive retail CM pays off and little insight into the costs and benefits" (GOONER, MORGAN, PERREAULT JR, 2011, p. 19). For a specific situation described, this paper shows some answers related to the role of category management and its effects on sales and market share.

Finally, from previous researchers it is possible to conclude that the category management process plays an important role in this context, because it can strengthen the supplier-retail relationship in order to generate more sales by also improving instore marketing. As a consequence, it is also important to consider the literature on shopper marketing and in-store marketing.

\section{Shopper marketing, in-store marketing and sales force execution}

A traditional belief states that more than half of the purchases are unplanned (KOLLAT and WILLETT, 1967; UNDERHILL, 2000) and researchers have agreed that unplanned purchases are more representative due to consumer susceptibility to in-store stimuli and due to some situational factors such as time available for shopping (PARK, IYER, SMITH, 1989; STILLEY, INMAN, WAKEFIELD, 2010). Beatty and Ferrell (1998) conclude that instore marketing can make shopping more efficient by helping the shopper find his or her planned items more quickly. Feijo and Botelho (2012) analyzed data from Brazil and concluded that merchandising factors have an influence on the consumer's store choice.

These previous findings help explain the reason for the increasing importance attributable by marketers and scholars to in-store marketing activities over recent years. Category management activity can influence the shopper along the path to purchase by creating in-store stimuli (GOONER, MORGAN, PERREAULT JR, 2011). 
According to the In-Store Institute and The Partnering Group (2010), the path to purchase consists of the following stages in which shoppers may be influenced: the first stage happens when shoppers are planning what they want or need and where they go to shop. The second stage happens when shoppers step into the stores to consider what to purchase. In this case, manufacturer and retailer activities that allow their brands to attract, engage, and motivate the purchase inside stores are important. At this stage, CM plays an important role to influence shoppers. Finally, the last stage is product experience, when consuming the product after the purchase.

Therefore, it is important to address the concept of shopper marketing. In the Journal of Marketing, this concept has started to be considered (BELL, CORSTEN, KNOX, 2011) and in the Journal of Retailing this concept has been reviewed, confirming its importance. According to Shankar and others (2011, p. 29), shopper marketing "refers to the planning and execution of all marketing activities that influence a shopper along, and beyond, the entire path-to-purchase". Considering the importance of shopper marketing, the first step of the analyzed category management process with small retailers in the experimental group was to understand the shopper, and then moving forward to the next steps as it is later mentioned in the method section.

Additionally, concerning the execution of marketing activities, the analyzed experiment was executed through the supplier's sales force. In this way, sales force is strongly responsible for the execution of business strategy (CHURCHILL and others, 2000). In a CPG, they can be responsible for implementing CM program among their tasks. Also, sales force plays an important role by establishing closer relationships with retailers.

In the situation we have analyzed, the company's sales force has provided store owners of the experimental group with support to organize its category's assortment, activate point of sale materials, and shelf-space in order to increase sales.

\section{Hypotheses}

In accordance with the theoretical review, we expect to validate our proposed hypotheses from the experiment described in this paper. A group of factors motivated us to propose the following hypotheses.

First, some evidences show that category management is open to companies of any type or size (ARKADER and FERREIRA, 2004) and sales lift is expected from the channel relationship established by means of a CM project (DUSSART, 1998; LINDBLOM and OLKKONEN, 2008). Therefore, CM can be an alternative to be applied to a different type of retailer, in this case, small neighborhood supermarkets. But previous studies have not yet tested this specific possibility. Also, sales force is important in the context of a CPG company for implementing business programs with retailers (QUELCH and CANNON-BONVENTRE, 1983). In this context, one manufacturer could use its sales force to implement a CM project in order to bring positive results. Thus:

$\mathrm{H}_{1}$ : The implementation of a category management initiative from the supplier's sales force has a positive effect on the manufacturer's sales for the specific category of the project.

Second, in-store marketing and shopper marketing practices offer conditions for a supplier to overcome competitors in the same store environment (BELL, CORSTEN, KNOX, 2011; SHANKAR and others, 2011). Taking into account that in-store marketing has a positive effect on sales (CHANDON and others 2009), and considering previous literature that also describes CM as a practice that creates conditions to improve instore marketing, it might be an alternative for one manufacturer that sponsors this type of project to gain market share, once the manufacturer strives to improve in-store marketing performance for its products in the category. Thus:

$\mathrm{H} 2$ : The implementation of a category management initiative from the supplier's sales force has a positive effect on the manufacturer's market share for the specific category of the project.

Finally, category management depends on the role of the manipulated category (DHAR, HOCH, KUMAR, 2001). As a consequence, it is also important to analyze the program looking at the performance of each category manipulated in the experiment. Therefore, from the perspective of a manufacturer that develops a CM project, we believe that their non-leader brands with lower market share, which were also included in this experiment, could be benefited as well, even when the orientation will be given to the market leader brand from a different category. Thus:

H3a: The implementation of a category management initiative brings market share growth for both the manufacturer's non-leader brands and leader brands.

However, it is important to consider that higher-market-share brands advertise more, have more awareness, and thus gain less from in-store improvements (CHANDON and others 2009). Thus:

$\mathrm{H}_{3} \mathrm{~b}$ : Market share growth from the implementation of a category management initiative is higher for the sponsored manufacturer's non-leader category than the growth for its market leader category when both are manipulated in the project. 
In the analyzed experiment, the manufacturer has also manipulated a second category in which they are not the market leader. Thus, its main competitor in this specific category is the market leader. Knowing that higher-market-share brands have more awareness and preference, having less impact from in-store movements (CHANDON and others 2009), we expect that the market share growth for a manipulated category where the manufacturer is not the market leader will be higher compared to the secondary brands instead of to the main competitor, because secondary brands generally have less awareness and preference than the main competitor. Thus:

$\mathrm{H}_{3} \mathrm{C}$ : Market share growth from the implementation of a category management initiative for a category in which the sponsored manufacturer is not the market leader is higher compared to secondary brands.

\section{CHANNEL ENVIRONMENT IN EMERGING MARKETS}

According to a contribution to the study of emerging markets, Sheth (2011) describes that emerging markets require practitioners and scholars to rethink marketing practices. Such practices include channel relationship activities among interdependent companies, and as previously described, category management can be associated with channel relationship literature because it involves the supplier's relationship with its channels, or intermediate companies (e.g., retailers) in order to make the offers available to consumers (DUSSART, 1998). ACcording to the 2011 A.T. Kearney Global Retail Development Index, developing countries represent $42 \%$ of global retail sales and local competition in these countries is stronger that it appears. However, channels' features for consumer products are different in emerging markets. As a consequence, it is important to address some specific features of grocery channels in these markets.

In developed markets, the earlier expansion of the supercenter format has boosted significant changes, bringing the so-called "one-stop-shopping" approach, when a retailer offers food items, non-food items and ancillary services. However, in emerging markets the entry of global retailers has happened after they had established their business in developed markets, leading to a different retailer environment.

The example of Wal-Mart illustrates the previous situation, because this retailer accelerated retail concentration in the USA (SINGH, HANSEN, BLATTBERG, 2006). While in the USA the first Wal-Mart store opened in 1962 and its first supercenter format opened in 1988, it was not until 1995 that Wal-Mart entered in the Brazilian market and only in 1996 in the Chinese market (ROCHA and DIB, 2002; SINGH, HANSEN, BLATTBERG, 2006).

As a result, a shift in power from manufacturers to corporate food retailers has been observed over the years (PLANET RETAIL, 2010), which can lead to a decrease in the rates of return obtained by manufactures as the bargaining power of retailers increases (PORTER, 1974; AILAWADI, BORIN, FARRIS, 1995). However, retail concentration in emerging markets is still lower than in developed markets (STIEGERT and KIM, 2009), boosting the importance of a multichannel perspective. Multichannel marketing can be a source of profitability (KUMAR and VENKATESAN, 2005; BERGER, LEE, WEINBERG, 2006; WILSON, STREET, BRUCE, 2008). The growth of emerging markets offers great opportunities to establish a multichannel marketing approach in which the importance of neighborhood stores is considered.

In these markets, small supermarkets have a significant share of sales; thus, global CPGs should explore this possibility, having better margins and less dependency on big chains. However, it is important to note that some specific contrasts must be considered for CPGs when comparing their approach to developed and developing markets, which also helps to justify the category management employed by a food company in one emerging market. Table 1 describes some of these contrasts.

In this way, establishing a relationship with neighborhood supermarkets is important for CPGs, because in this retail format, store owners are often making decisions on assortment, shelf-space, price, and in-store marketing. Considering the purpose of a CM process, it may strengthen the supplier-retailer relationship in a neighborhood supermarket environment, once suppliers are willing to help retailers manage their category.

Specifically, with regards to retail concentration in Brazil, over time there has been a consolidation of retailers who have become more powerful such as Wal-Mart, Carrefour and the Pão de Açúcar Group, resulting in increasing buying power over manufacturers. However, neighborhood supermarkets are still important in the country. According to Nielsen (2007), small Brazilian supermarkets that have one to four checkouts were responsible in 2003 for $11 \%$ of total sales to final consumers among all types of food retailers. In 2007 , this share increased to $13 \%$. In 2008 , small supermarket sales increased by $2.3 \%$ compared to the previous year and in 2009 sales increased by $7 \%$ compared to 2008 (NIELSEN, 2010).

To reach Brazilians, CPG companies should be prepared to adapt their marketing strategy considering a wide range of channels and the importance of neighborhood stores, because this format is the one with more penetration from different social economic classes. 


\section{TABLE 1. Grocery channels in developed and in emerging markets}

\begin{tabular}{l|l|l|l}
\hline Grocery Channels & Developed Markets & Emerging Markets (Brazil) & Implications for CPGs in Emerging Markets \\
\hline $\begin{array}{l}\text { Corporate chains } \\
\text { versus } \\
\begin{array}{l}\text { Individual ownership } \\
\text { and independent } \\
\text { stores }\end{array}\end{array}$ & $\begin{array}{l}\text { Stores that belong to } \\
\text { corporate groups are } \\
\text { predominant }\end{array}$ & $\begin{array}{l}\text { Due to the importance of convenience } \\
\text { shopping, independent stores, that are } \\
\text { conveniently located in neighborhoods, } \\
\text { have a significant share of sales and tend } \\
\text { to remain important over the years }\end{array}$ & $\begin{array}{l}\text { Services that may strengthen the } \\
\text { relationship between brands and store } \\
\text { owners are of importance to be established } \\
\text { with smaller stores }\end{array}$ \\
\hline $\begin{array}{l}\text { Big stores versus } \\
\text { small stores }\end{array}$ & $\begin{array}{l}\text { High level of } \\
\text { concentration of big } \\
\text { stores }\end{array}$ & $\begin{array}{l}\text { Smaller stores are generally more } \\
\text { conveniently located to shoppers and the } \\
\text { level of concentration of big stores is still } \\
\text { lower than in developed markets }\end{array}$ & $\begin{array}{l}\text { Smaller stores have a more limited } \\
\text { is a challenge and manufacturers should } \\
\text { develop specific marketing programs to } \\
\text { overcome competition in this channel }\end{array}$ \\
\hline
\end{tabular}

Source: Developed by the authors based on Rocha and Dib, 2002; Singh, Hansen and Blattberg, 2006; Stiegert and Kim, 2009; Deloitte, 2010; Cleeren and others, 2010.

For example, a study by McKinsey \& Company (KERTESZ and others, 2011), using data from LatinPanel and Nielsen, shows that neighborhood supermarkets have on average $29 \%$ of consumers from classes A/B, 38\% from middle class, and $33 \%$ from classes $D / E$. Thus, the importance of this channel in this emerging market also relies on the growing middle-class population because this channel has a high penetration in this class. The same authors conclude that having different actions for the different channel formats is increasingly important in Brazil, such as for neighborhood stores (KERTESZ and others, 2011).

\section{METHODOLOGY AND PROCEDURES}

Gupta and Steenburgh (2008) conclude that in marketing literature, experiments are a powerful method for understanding the market response to new marketing activities that the firm has not tried historically. In this paper, we analyze the category management process, which was applied as a new marketing activity developed by one manufacturer and a sample of small retailers, allowing us to set up test-and-control samples to assess the effectiveness of the referred category management program.

Thus, this research uses a quantitative approach after a field experiment has been conducted by a large CPG, in which 180 small family-owned supermarkets participated in the company's category management program, called the experimental group in this paper.. The other group of similar store features served by the same company that were not included in the company's category management program is called the control group.

For research development, the following stages were taken: i) we first conducted a review of academic literature on category management, in-store marketing and sales force execution aimed at extracting potential ideas in order to tailor a frame- work of category management that could be applied to small independent supermarkets, considering their features in Brazil; ii) training the company's sales force team to execute the program in the stores they had selected, according to concepts and practices revised during the previous stage; iii) pre-testing the field, called the pilot project in this paper, in order to adjust and validate the CM process according to a smaller-store environment; iv) implementation of the company's program with 180 small family-owned supermarkets through the sales force team; v) separation between the experimental group and the control group, according to the company's customer database for the analyzed type of store, in which the experimental group and the control group had similar features as the other group (e.g. store size, shopper profile, geographic location); vi) sales and market-share data collection related to the experimental and control group from the company's internal system; vii) analysis of the sales and market-share of the company in the experimental and control group stores; viii) finally, a quantitative analysis was conducted in order to analyze available data and to assess the effect of the program on the food manufacturer's sales and market share, as proposed in this research.

\section{Data and framework}

The data available for this research includes sales and market share variables from the analyzed CPG company in Brazil, according to monthly data ranging from July 2008 to June 2010 . The experiment was implemented in the southeast of Brazil. Some steps were considered by the CPG's sales force in order to develop a category management review in each experiment store, including store layout, assortment, product shelf position, product's in-store visibility, promotion and price. In this sense, the sales force followed steps from the CM framework for small supermarkets proposed by Guissoni, Consoli and Castro (2010). 
TABLE 2. Data scope and sample features

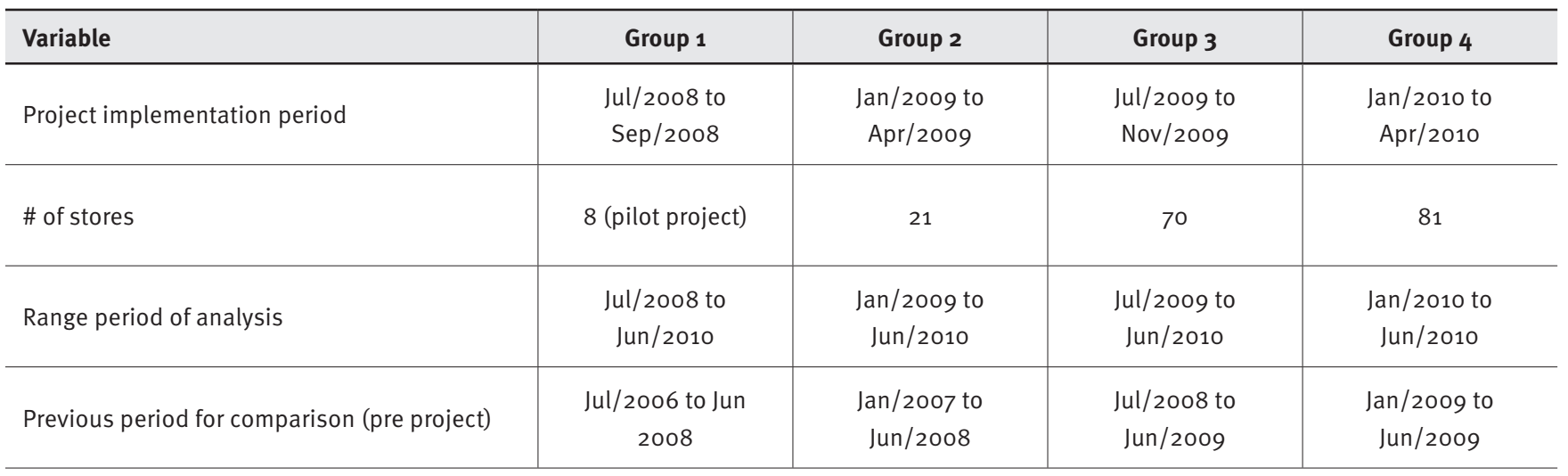

According to the related framework implemented in this experiment after the shopper and retailer understanding, the sales force team from the analyzed CPG should suggest to each experiment store: (i) the categories to be offered; (ii) the store layout to place the categories according to their role; (iii) the assortment, that is, the most appropriate SKUs to be offered considering previous steps; (iv) the in-store materials to be used to promote the categories in the project stores.

In the implementation, due to a decision from the CPG company, this initiative was implemented according to different phases, including a different set of stores for each phase. All sample stores were small independent supermarkets with 1 to 4 checkout lanes. Table 2 presents the main information for implementing the initiative.

Data analysis was also broken down by product category where Category 1 refers to non-alcoholic beverages, and Category 2 to alcoholic ones. Both categories were manipulated in the field experiment. Additionally, we evaluated results considering the focal company's data (Company), the main competitor (Competitor 1) and secondary brandcompetitors (Competitor 2). It is important to note that for category 1 , the focal company is the market leader. However, for category 2 the company is not the market leader, since competitor 1 is the market leader. In order to have a comparison base, all data was transformed into a 100 base sequence after the first month considered in the period range analysis.

We analyzed the data from the project stores (i.e., experimental group) consisting of 180 stores and the control group, including 2,500 stores with similar features as the experimental group as described in this paper, which also have 1-4 checkouts and are served by the company in the same regions as the other group. Following the period of analysis, available data from each store shared by the company for this paper were: i) company sales volume for experimental and control groups for category 1 and company market share for both, categories 1 and 2 .

\section{Procedures}

Since this paper questions whether a CM initiative with small retailers is worth the effort, it is important to analyze sales and market share effects as a result of this experiment. To make this possible and considering the available data, we performed a variance analysis (ANOVA) in three different applications. In the first one, sales differences in the project stores considered pre- and post- implementation data. Secondly, we focused on comparing the means between project stores and the control group's sales. In order to check the control group, we have also compared sales differences in the control group stores considering pre- and post- implementation. Finally, specifically for market-share, another set of variance analysis was also performed comparing company market share evolution to competing companies in the same period.

\section{RESULTS}

Before analyzing the effect of category management programs on sales and market-share, a Kolmogorov-Smirnov test, which is a normality test, was performed for each sample regarding sales and market-share variables. This test is important because in order to conduct an analysis of variance (i.e., ANOVA), the distribution of the values must be close to a normal distribution.

The Kolmogorov-Smirnov tests of the sales and market share variables for both the experimental and control groups allowed us to observe that the distribution is normal since the $p$-value of samples is greater the 0.05 . Thus, the analysis of variance can be used as a way to compare the variables from the groups, validating the procedures presented and applied to this research.

Following our analysis, Table 3 illustrates that groups 1 and 4 presented better sales performance for non-alcoholic beverages. For group 1, in terms of sales volume, project store 
sales increased $39.37 \%$ compared with pre-project data, and $5.36 \%$ compared with control group; although, control group performance was $6.14 \%$ higher post $x$ pre-project. As only 8 stores are in this group, we still considered the result as positive. It is important to note that group 1 has the longest data set and having its period analysis starting and finishing in the winter, no inverse relation due to seasonality was identified (as it is a beverage category). The Group 2 data set on the other hand, started late summer and finished in the winter. Thus, company sales are expected to decrease in the winter; so, better results in this case are those with lower sales reductions. We can see that control group sales decreased in the period $11.95 \%$ while project stores fell $13.67 \%$, contrary to what we expected, possibly due to inventory, seasonality and the implementation process. The results for group 3 present inverse relations as data sets started late winter, have a full summer and finished in the winter again. We also verified that total sales pre versus post-project increased more in the control group (9.95\%) than in the project stores (6.07\%). Finally, group 4 results presented positive effects on sales, where project store sales increased $31.80 \%$ compared with pre-project data and the biggest difference between project stores and control group was identified (23.46\%).

Following the ANOVA test, specifically for group 1, we considered there was a difference in terms of sales performance for project stores, pre $x$ post experiment, at $10 \%$ of significance level $(p$-value $=0.0674)$. In the other cases, sales differences were significant at $5 \%$, as shown in Table 4 . Moreover, significant differences happened in group 2 between project stores versus control group ( $p$-value $=0.0006$ ) as well as control group pre and post-project ( $p$-value $=0.0351$ ). Similarly, group 4 presented a significant difference in sales performance pre and post-project ( $p$-value $=0.02912$ ) as well project stores versus control group $(p$-value $=0.03568)$.

\section{TABLE 3. Sales performance for non-alcoholic beverages for the category management program}

\begin{tabular}{|c|c|c|c|c|}
\hline Sales performance $\mathrm{x}$ baseline (Initial period $=100$ ) & Group 1 & Group 2 & Group 3 & Group 4 \\
\hline Project stores (post) x control group (post) & $5.36 \%$ & $0.49 \%$ & $-2.50 \%$ & $23.46 \%$ \\
\hline Control group (pre-project x post-project) & $6.14 \%$ & $-11.95 \%$ & $9.95 \%$ & $11.02 \%$ \\
\hline
\end{tabular}

TABLE 4. ANOVA of the sales variable for non-alcoholic beverages

\begin{tabular}{|c|c|c|c|c|}
\hline Variance analysis & $\begin{array}{l}\text { Group } 1 \\
\text { P-value }\end{array}$ & $\begin{array}{l}\text { Group } 2 \\
\text { P-value }\end{array}$ & $\begin{array}{l}\text { Group } 3 \\
\text { P-value }\end{array}$ & $\begin{array}{l}\text { Group } 4 \\
\text { P-value }\end{array}$ \\
\hline Anova pre-project x post-project & $0.0674^{*}$ & 0.9797 & 0.2824 & $0.02912^{\star \star}$ \\
\hline Anova project stores $x$ control group & 0.6748 & $0.0006^{* * *}$ & 0.86 & $0.03568^{\star *}$ \\
\hline Anova control group (pre-project x post-proj.) & 0.6975 & $0.0351^{\star \star}$ & 0.9086 & 0.3879 \\
\hline
\end{tabular}

* Significant at $p<10 \%$; ** Significant at $p<5 \%$; *** Significant at $p<1 \%$

Based on the results, a positive overall effect of the project on manufacturer category sales can be found, excepting for groups 2 and 3 . Therefore, we have partially confirmed $\mathrm{H}_{1}$ as explained in the sequence of this article, because in order to consistently validate and explain results from tables 3 and 4, after performing this analysis we interviewed six company sales supervisors responsible for implementing the project for all groups. The motivation was to better understand sales results for groups 2 and 3, once the analysis of variance suggested that some of the sales differences were not significant.

The interviews allowed us to understand any evidence from the implementation that might have interfered in the sales results for the experimental group. According to the sales super- visors, when they tried to scale up the project (groups 2 and 3), they did not perform the first steps from the applied framework (i.e., shopper and retailer understanding) well while planning the category management program for stores in groups 2 and 3 , once the number of stores had increased after the pilot project. However, as a learning process to implement CM under a different retail environment, they were able to improve the process in order to scale up the project. This could be seen in the results of group 4 , when they achieved better results.

In terms of market share growth, the analysis also shows an overall positive effect across the groups. However, as we did not have market share historical data for group 1 (project pilot), its evolution could not be evaluated. Interest- 
ingly, groups 2 and 4 presented the best performance in market share analysis. All variance analyses presented in Table 5 were significant at the $5 \%$ level.

TABLE 5. Effects of the category management program on market-share

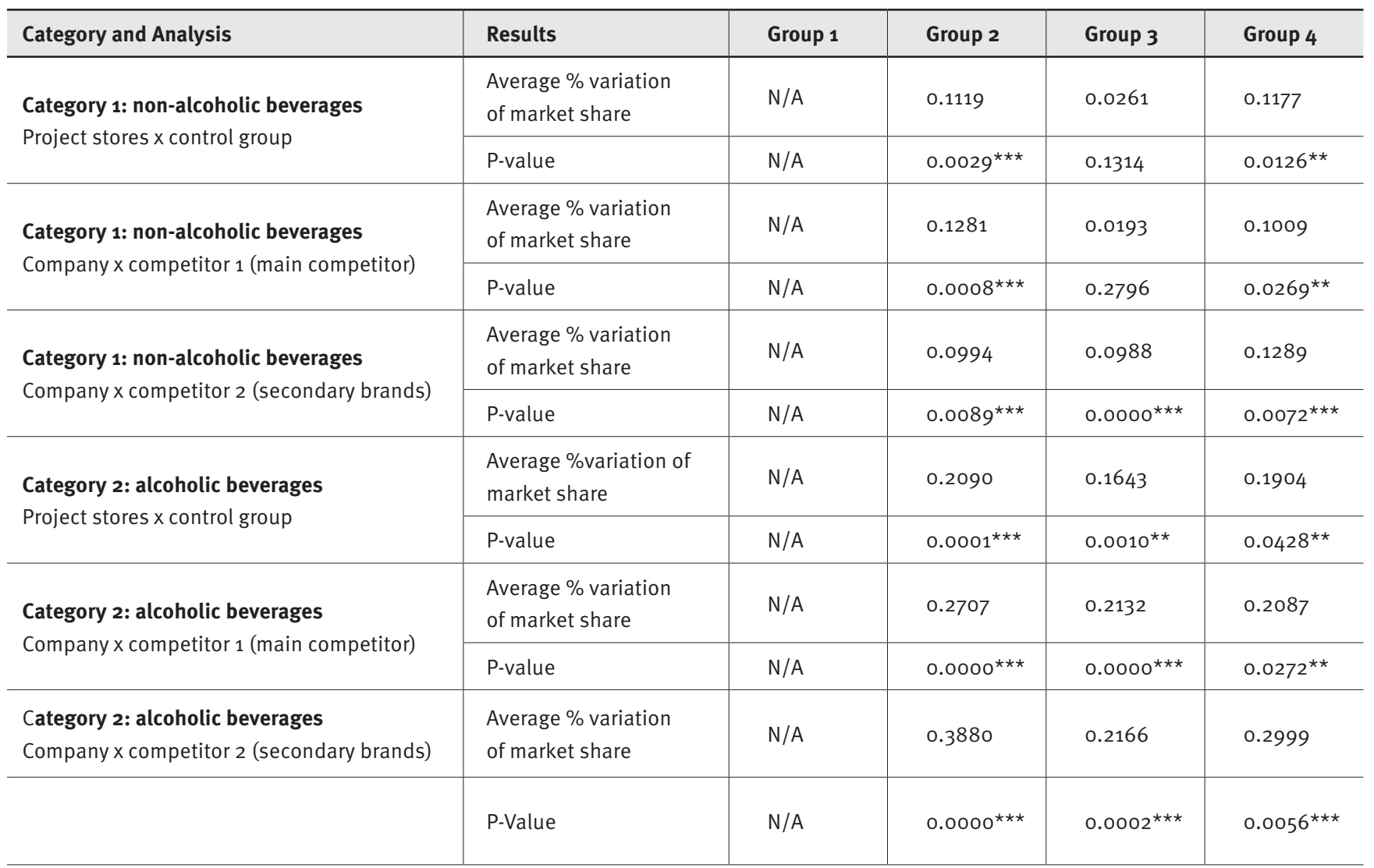

* Significant at p $<10 \%$; ** Significant at p $<5 \%$; *** Significant at p $<1 \%$

In this way we found results to be positive, which corroborates hypothesis $\mathrm{H}_{2}$. As previously stated in the procedures, absolute market share at the beginning of the project was used as 100 base and further analysis considers the relative increases over this base. Taking group 2 to illustrate the analysis presented in table 5 , market share of category 1 , that is, non-alcoholic beverages, for project stores increased $11.19 \%$ compared to the increase of control group, and $12.81 \%$ compared to the main competitor. For category 2 , that is, alcoholic beverages, in which the company is not the market leader, market share growth was even higher. The market share increase for project stores compared to the control group was $20.9 \%$. When compared to the main competitor for this specific category, the increase was $27.07 \%$. Finally, the increase was $38.8 \%$ when compared to secondary brands.

Moreover, market share growth happened for both manufacturers' manipulated categories, which corroborates $\mathrm{H}_{3 \mathrm{a}}$. However, for all groups the market share increase was high- er in the category in which the manufacturer is not the market leader, allowing us to confirm $\mathrm{H}_{3 \mathrm{~b}}$. Also, some similarities were found across all groups with regards to market share analysis. For example, overall performance of category 2 was quite positive, mainly against secondary brand competitors. That is, despite the growth of market share against both the main competitor and secondary brands within the category, this project contributed for the manufacturer to further increase its market share compared to competing secondary brands in the category in which they are not market leader, allowing us to confirm $\mathrm{H}_{3 c}$.

Based on the previous analysis, we confirmed both hypotheses, since evidences of an overall positive effect on both sales and market share were found across the groups. Results show that the implementation of category management as a service offered by the manufacturer's sales force to small neighborhood supermarkets besides increasing category sales, seems to have a positive effect for a manufacturer to overcome competitors in terms of market share. 


\section{CONCLUSIONS AND MANAGERIAL IMPLICATIONS}

Considering that "suppliers must move away from purely transactional relationships with their retail customers and more towards a partnership" (PLANET RETAIL, 2010, p. 1), the conducted research is relevant, once this was the purpose of the category management program developed by one Brazilian company in order to increase sales. The results from this project were analyzed aiming to stimulate debate and contributions for future discussions among researchers on this subject.

This paper is a result of a specific supplier initiative focusing on small supermarkets in Brazil, which was implemented involving category management review for the project's stores.

Our results are consistent with previous CM researches on developed markets and big supermarkets, since we could confirm our hypotheses (excepting $\mathrm{H}_{1}$ for groups 2 and 3 possibly due to the scale up factor), showing a positive sales impact of category management on project stores, consisting of small independent neighborhood supermarkets. Moreover, results confirmed the positive effects of such an initiative on company market share, increasing its competitiveness. In this way, the results are consistent with studies that describe CM efforts as a way to increase sales (KOLLAT and WILLETT, 1967; LINDBLOM and OLKKONEN, 2008; UNDERHILL, 2000; GOONER, MORGAN,PERREAULT JR, 2011).

From the results, we can look at the performed experiment as category management giving firms the ability to improve on basic positive trends, but not able to stop negative ones due to several factors (e.g., seasonality). Also, it is interesting to note a kind of side effect of category management for manufacturers that carry both leader and non-leader brands. In this case, $\mathrm{H}_{3 \mathrm{~b}}$ was confirmed. In category 2, the analyzed manufacturer does not have the same brand power as in category 1 , as they are not market leader. However, the growth of market-share for this non-leader category was higher in the experiment than for the category in which they are market leader. In this case, for this experiment to happen, the manufacturer took advantage of its brand power in category 1 , as a market leader, in order to persuade small retailers to join the $\mathrm{CM}$ program in which their two categories would be manipulated. This strategy allowed the manufacturer to further stimulate better management of its brands in category 2 of alcoholic beverages in the stores' projects, in accordance with presented results.

In a nutshell, our findings suggest that a manufacturer can use its influence in one category with leader brands to improve results for its other category with non-leader brands by managing both categories and following a CM process in a small neighborhood store environment. Besides, market share increase was consistently higher against secondary brands than compared to the main competitor in the category, which corroborates $\mathrm{H}_{3 c}$. The same result was verified for both manipulated categories.

In this research, we propose to contribute to the literature by showing the worth of a $\mathrm{CM}$ initiative from a manufacturer perspective in a representative channel that is, small neighborhood supermarkets, in emerging markets. Theses perspectives can contribute to the literature, since most previous researches have investigated their effects from a retailer implementation perspective, mostly taking place in developed markets and in big supermarket channels.

Considering however the $\mathrm{CM}$ as a process that can contribute to the supplier-retailer relationship and benefit both parties, if retailers in this kind of project are not benefited, they tend to not accept CM programs proposed by a specific manufacturer. In this way, future research should investigate the joint effect of a CM program from both parties, that is, manufacturers and retailers.

In this sense, examples of research questions might include: What are the effects of a specific category management initiative for both, manufacturers and retailers? Does CM improve total category sales in the stores' project or only the share of supplier's sales? Is CM an alternative to improve profits for one specific category for retailers? Are manufacturers' decisions of assortment and in-store marketing biased to protect only its interest during a CM program? Also, by comparing the results of each store project would it be possible to investigate what the main drivers for developing an effective CM program are? Answers to these questions have the potential to contribute to academics and practitioners.

Some limitations of our research can be related to some occasional events that affected the market in which we applied our research, as well limitations of data and procedures used to implement the project, as it was the company's sales force's responsibility. Also, one of the limitations is the lack of more complete data coming from retailers.

Considering the importance of a channel push activity under the context of this study, and the importance of emerging markets, this paper shows that providing services to independent retailers, such as category management support in order to help them organize their stores in terms of having an appropriate assortment, layout and in-store marketing, can create overall positive effects on manufacturer sales and market share. Therefore, allocating efforts for a category management initiative with small supermarkets can be an interesting strategy in an emerging market environment, such as Brazil. 


\section{NOTE OF APPRECIATION}

The authors would like to thank the anonymous reviewers for their constructive suggestions. They would also like to thank the professors Paul W. Farris and Rajkumar Venkatesan for their valuable contributions to the research.

\section{REFERENCES}

AILAWADI, K. L; BORIN, N; FARRIS, P. W. Market power and performance: a cross-industry analysis of manufactures and retailers. Journal of Retailing, v. 71, n. 3, p. 211-248, 1995.

ANDERSON, J. C; NARUS, J. A. A model of distributor firm and manufacturer firm working partnerships. Journal of Marketing, v. 54, n. 1, p. 42-58, 1990.

ARKADER, R; FERREIRA, C. F. Category management initiatives from the retailer perspective: a study in the Brazilian grocery retail industry. Journal of Purchasing \& Supply Management, v. 10, n. 1, p. 41-51, 2004.

A.T. KEARNEY, 10th annual Global Retail Development Index (GRDI). Chicago: A.T. Kearney, 2011

BEATTY, S. E; FERRELL, E. M. Impulse buying: modeling its precursors. Journal of Retailing, v. 74, n. 2, p. 169-191, 1998.

BELL, D. R; CORSTEN, D; KNOX, G. From point of purchase to path to purchase: how preshopping factors drive unplanned buying. Journal of Marketing, v. 75, n. 1, p. 31-45, 2011.

BERGER, P. D; LEE, J; WEINBERG, B. D. Optimal cooperative advertising integration strategy for organizations adding a direct online channel. Journal of the Operational Research Society, v. 57, n.8, p. 920-927, 2006.

CATEGORY MANAGEMENT REPORT. The Joint Industry Project on Efficient Consumer Response. 1995.

CHANDON, P; HUTCHINSON, J. W; BRADLOW, E. T; YOUNG, S. H. Does in-store marketing work? Effects of the number and position of shelf facings on brand attention and evaluation at the point of sales. Journal of Marketing, v. 73, n. 6, p. 1-17, 2009.

CHATTERJEE, I; KUPPER, J; MARIAGER, C; MOORE, P; REIS, S. The decade ahead: trends that will shape the consumer goods industry. Mckinsey Consumer Shopper Insights, 2011. Available at: http://csi.mckinsey. com/Home/Knowledge_by_topic/Consumer_and_shopper_insights/ decadeahead.aspx. Access on 02.10.2012.

CHURCHILL, A. G; FORD, N. M; WALKER, O. C; JOHNSTON, M. W; TANNER, J. F. Sales force management. 6. ed. Irwin: McGraw-Hill, 2000.

CLEEREN, K; VERBOVEN, F; DEKIMPE, M. G; GIELENS, K. Intra- and interformat competition among discounters and supermarkets. Marketing Science, v. 29, n. 3, p. 456-473, 2010.

DELOITTE RESEARCH. Shopper Marketing: capturing a shopper's mind, heart and wallet. New York: Deloitte Development, 2007.

DELOITTE RESEARCH. Hidden heroes: emerging retail markets beyond China. London: The Creative Studio at Deloitte Development. 2010.
DHAR, S. K; HOCH, S. J; KUMAR, N. Effective category management depends on the role of the category. Journal of Retailing, v. 77, n. 2, p. 165-184, 2001.

DÍAZ, A; LACAYO, J. A; SALCEDO, L. Selling to 'mom-and-pop' stores in emerging markets. Mckinsey Quartely, 2007. Available at: http:// www.mckinseyquarterly.com/Selling_to_mom-and-pop_stores_in_ emerging_markets_1957. Access on 03.20.2012.

DUSSART, C. Category management: strengths, limits and developments. European Management Journal, v. 16, n. 1, p. 50-62, 1998.

ETGAR, M. Intrachannel conflict and use of power. Journal of Marketing Research, v.15, n. 2, p. 273-274, 1978.

FEIJÓ, F. R; BOTELHO, D. The effect of factors related to merchandising on retail sales. RAE-Revista de Administração de Empresas, v. 52, n. 6, p. 628-642, 2012.

FRAZIER, G. L; SUMMERS, J. O. Interfirm influence strategies and their application within distribution channels. Journal of Marketing, v. 48, n. 3, p. 43-55, 1984.

GANESAN, S; GEORGE, M; JAP, S; PALMATIER, R. W; WEITZ, B. Supply chain management and retailer performance: emerging trends, issues, and implications for research and practice. Journal of Retailing, v. 85, n. 1, p. 84-94, 2009.

GOONER, R. A; MORGAN, N. A; PERREAULT JR., W. D. Is Retail category management worth the effort (and does a category captain help or hinder)? Journal of Marketing, 75, n. 5, p. 18-33, 2011.

GRUEN, T. W; SHAH, R. H. Determinants and outcomes of plan objectivity and implementation in category management relationships. Journal of Retailing, 76, n. 4, p. 483-510, 2000.

GUISSONI, L. A; CONSOLI, M. A; CASTRO, L. T. Proposta de gerenciamento por categoria pequeno varejo: do planejamento à virada de loja. In: EMA 2010 - IV Encontro de Marketing da ANPAD, 2010, Florianópolis. Anais. Florianópolis: ANPAD, 2010.

GUPTA, S; STEENBURGH, T. Allocating marketing resources. In: KERIN, R. A; O'REGAN, R. (Eds) Marketing mix decisions: new perspectives and practices. Chicago, IL: American Marketing Association, 2008. p. 3-37.

HIBBARB, J. D; KUMAR, N; STERN, L. W. Examining the impact of destructive acts in marketing channel relationships. Journal of Marketing Research, v. 38, n. 1, p. 45-61, 2001.

JÜTTNER, U; CHRISTOPHER, M; BAKER, S. Demand chain managementintegrating marketing and supply chain management. Industrial Marketing Management, v. 36, n. 3, p. 377-392, 2007.

KERTESZ, A; FRANCIS, T; FURTADO, B; CAFRUNI, R. Five things to know about Brazil's fast-moving consumer market. Mckinsey Consumer Shopper Insights, 2011. Available at: http://csi.mckinsey.com/ Knowledge_by_region/Americas/brazilconsume. Access on 03.05.2012.

KOLLAT, D. P; WILLETT, R. P. Customer impulse purchasing behavior. Journal of Marketing Research, v. 4, n. 1, p. 21-31, 1967.

KUMAR, V; VENKATESAN, R. Who are the multichannel shoppers and how do they perform? Correlates of multichannel shopping behavior. Journal of Interactive Marketing, 19, n. 2, p. 44-62, 2005

LINDBLOM, A; OLKKONEN, R. An analysis of suppliers' roles in category management collaboration. Journal of Retailing and Consumer Services, v. 15, n. 1, p. 1-8, 2008.

NIELSEN. Mudanças no mercado brasileiro. In: Seminário Nielsen Tendências. São Paulo, 2007.

NIELSEN. Mudanças no mercado brasileiro. In: Seminário Nielsen Tendências. São Paulo, 2010. 
PARK, C. W; IYER, E. S; SMITH, D. C. The effects of situational factors on in-store grocery shopping behavior: the role of store environment and time available for shopping. Journal of Consumer Research, 15, n. 4, p. 422-433, 1989.

PLANET RETAIL. Power shift in FMCG: how retailers are in control and what suppliers can do about it. Planet Retail Limited: London. 2010.

PORTER, M. E. Consumer behavior, retailer power and market performance in consumer goods industries. The Review of Economics and Statistics, v. 56, n. 4, p. 419-436, 1974

QUELCH, J. A; CANNON-BONVENTRE, K. Better marketing at the point of purchase. Harvard Business Review, v.61, n. 6, p.162-169, 1983.

ROCHA, A; DIB, L. A. The entry of Wal-Mart in Brazil and the competitive responses of multinational and domestic firms. International Journal of Retail \& Distribution Management, v. 30, n. 1, p. 61-73. 2002.

RUNYAN, R. C; STERNQUIST, B; CHUNG, J. Channel relationship factors in cross-cultural contexts: antecedents of satisfaction in a retail setting. Journal of Business Research, v. 63, n. 11, p. 1186-1195, 2010.

SHANKAR, V; INMAN, J. J; MANTRALA, M; KELLEY, E; RIZLEY, R. Innovations in shopper marketing: current insights and future research issues. Journal of Retailing, v. 87, n. 1, p. 29-42, 2011.

SHETH, J. N. Impact of emerging markets on marketing: rethinking existing perspectives and practices. Journal of Marketing, v. 75, n. 4, p. 166-182. 2011.

SINGH, V. P; HANSEN, K. T; BLATTBERG, R. C. Market entry and consumer behavior: an investigation of a Wal-Mart supercenter. Marketing Science. 25, n. 5, p. 457-476, 2006.

STIEGERT, K. W; KIM, D. H. Structural changes in food retailing: six country case studies. Madison: Food System Research Group, University of Wisconsin-Madison, 2009.

STILLEY, K. M; INMAN, J. F; WAKEFIELD, K. L. Planning to make unplanned purchases? The role of in-store slack in budget deviation. Journal of Consumer Research, v. 37, n. 2, p. 264-278, 2010.

UNDERHILL, P. Why we buy: the science of shopping. New York: Simon \& Schuster. 2000.

WILSON, H; STREET, R; BRUCE, L. The multichannel challenge: integrating customer experiences for profit. Oxford: Butterworth- Heinemann, 2008. 